of general paralysis; a striking difference between them is often observable even to the naked eye. In the latter case, a series of streaks or lines may frequently be seen radiating through the white and grey substances towards the surface; and in vertical sections of convolutions that have been hardened in chromic acid, it is very common to perceive, in the white substance especially, what seems at first sight to be a number of vertical fissures and oval slits, which, under the microscope, however, are found to contain bloodvessels surrounded by sheaths like those already described. But the sheaths in these cases are often less delicate; they are thicker, more conspicuous, and frequently darker than in the healthy brain; and sometimes, especially when the vessels are convoluted, they appear as fusiform dilatations along their course. Moreover, while in the healthy brain the granules or grains of hæematoisin are commonly scanty, and frequently absent altogether, in general paralysis they mostly abound, being scattered in some places, and collected into groups in others. So much for the state of the cerebral bloodvessels in general paresis. In the nerve-cells of the convolutions I have frequently discovered certain structural changes, which, as far as $I$ am aware, have not been mentioned by other observers. These changes consist of an in rease in the number of the contained pigmentgranules, which in some instances completely fill the cell. In other instances the cell loses its sharp contour, and looks like an irregular heap of particles ready to fall asunder. *

A French writer, M. Joire, has stated that, during an experience of three years, he has always found in cases of general paralysis a peculiar alteration of structure in the fourth ventricle of the brain. This alteration consists of the formation of a considerable number of granulations resembling the elevations produced on the skin under the influence of cold. At an early stage of the disease the granulations are numerous and small, and suggest the idea of a surface covered with grains of sand. In older cases the granules are larger, and afford a rough sensation to the touch. They are most remarkable at the point of the calamus scriptorius. 't

The appearance described by M. Joire is quite familiar to me, but I have not always found it in general paralysis; and it is certainly not peculiar to this disease, for $I$ found it in cases of an entirely different nature. In Beale's "Archives of Medicine" (No. ix., 1861), I recorded a remarkable case of muscular atrophy, in which, together with lesions of the cord, this granular appearance on the floor of the fourth ventricle was very strikingly manifested. I then showed that it was due to hypertrophy of the ordinary epithelium by which the ventricle is lined. It may be well to reproduce my description. "The whole floor of the fourth ventricle presented a very peculiar and unnatural aspect. Instead of being smooth and shiny, as in the healthy state, it was entirely paved with a multitude of granulations or small rounded eminences, which were very closely aggreyated, but differed from each other considerably in size. I removed some of them for examination, first by scraping them off from the surface, to which they adhered with considerable tenacity; and then by shaving off a section, together with a thin layer of the subjacent tissue. When examined by a sufficiently high masnifying power, the granulations or eminences were seen to consist of globular aggregations of the ordinary epithelial cells, which, in a natural or healthy state, are arranged side by side, and form a smooth or level surface on the floor of the ventricle. The tissue immediately subjacent, and which consists of exceedingly fine fibres proceeding from the tapering ends of the epithelial cells, and running in various directions, was more abundant than usual ; and-as might be expected from the homologous rela. tion of this part to that which surrounds the spinal canal-it was interspersed with corpora amylacea, but certainly not to a corresponding extent " +

In protracted cases of general paralysis the spinal cord is mostly, if not always, more or less affected. In some instances I have found it softened in certain parts to the consistence of cream. In other instances, in which there was little or no external appearance of softening, I have found numerous areas of granular and fluid disintegration within and around the grey substance.

Belgravia, Ang. 1866.

* These are not to be confounded with the "granule" or "exudation" cells of authors. The filling of the nerve-cells with pigment-granules, as an early stage of degeneration. I formerly pointed out in diseases of the spinal cord and of other parts.--(Beale's " Archives of Mledicine," No. xiii.) Dr. Hughes Bennett had also described fatty degeneration and consequent disintegration of nerve-cells in the nervous centres. This distinguished pathologist has represented the change in Fig. 405 of his great work on "The Principles and Practice of Medicine," tourth edition.

t Gazette Médicale de Paris Ang, 1864

t+ Beale's "Archives of Medicine," No. ix., Oct. 1s61, p. 18.
ON THE

AMOUNT OF FRESH AIR REQUIRED TO REDUCE TO THE NORMAL STANDARD THE CARBONIC ACID IN AIR VITIATED BY RESPIRATION.
BY STAFF-SURGEON F. DE CHAUMONT, M.D., ASSISTANT PROFESSOR OF HYGIHAE, ARMY MEDICAL SCHOOL.

THe principles brought forward in the section on Ventila. tion in Dr. Edward Smith's report on the Workhouse Infirmaries are so much at variance with the hitherto received. ideas on the subject that $I$ have thought it would be useful to analyze some detailed observations made during the last few years.

Dr. Smith asserts that the recommendations of the Barrack and Sanitary Commissions are founded on theory only, and that there are no experiments with which to compare those made by himself in conjunction with Dr. Angus Smith. $\mathrm{He}$ further states that a space of 500 cubic feet per man is sufficient, provided there be an adequate renewal of air. It is evident that Dr. E. Smith cannot have read the papers published on the subject (by myself and others) in the Army Medical Reports during the last four or five years. In these will be found experiments even more extended and in more detail than his own. I propose to analyze a few of them, and, to facilitate this, I have constructed the following table, which shows the amount of air required to be delivered to reduce to a given standard the carbonic acid in an atmosphere vitiated by respiration.

Table showing the diminution of the ratio of $\mathrm{CO}_{2}$ in vitiated ais by delivery of definite quantities of fresh air; the original air-space being 1000 cubic feet, occupied by one adult.

\begin{tabular}{|c|c|c|c|c|c|}
\hline 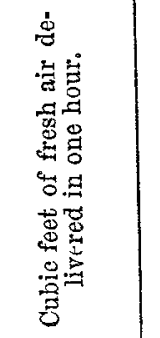 & 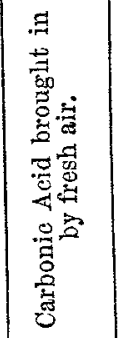 & 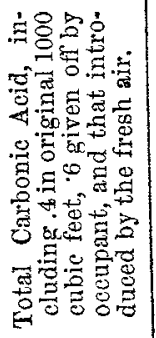 & 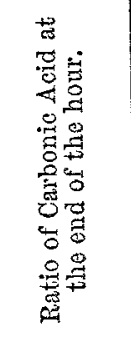 & 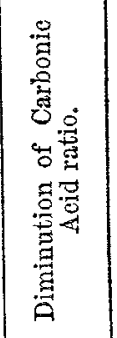 & REMARES, \\
\hline \begin{tabular}{r|}
$n i l$ \\
1,000 \\
2,000 \\
3,000 \\
4,000 \\
5,000 \\
6,000 \\
7,000 \\
8,000 \\
9,000 \\
10,000 \\
11,000 \\
12,000 \\
13,000 \\
14,000 \\
15,000 \\
16,000 \\
17,000 \\
18,000 \\
19,000 \\
20,000 \\
25,000 \\
30,000 \\
40,000 \\
45,000 \\
50,000 \\
100,000 \\
$1,000,000$
\end{tabular} & 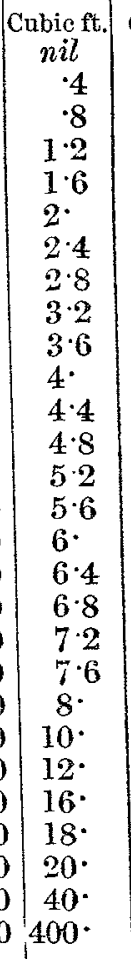 & $\begin{array}{c}\text { Cubic feet. } \\
1 \cdot \\
1 \cdot 4 \\
1 \cdot 8 \\
2 \cdot 2 \\
2 \cdot 6 \\
3 \cdot \\
3 \cdot 4 \\
3 \cdot 8 \\
4 \cdot 2 \\
4 \cdot 6 \\
5 \cdot \\
5 \cdot 4 \\
5 \cdot 8 \\
6 \cdot 2 \\
6 \cdot 6 \\
7 \cdot \\
7 \cdot 4 \\
7 \cdot 8 \\
8 \cdot 2 \\
8 \cdot 6 \\
9 \cdot \\
11 \cdot \\
13 \cdot \\
17 \cdot \\
19 \cdot \\
21 . \\
41 . \\
401 .\end{array}$ & 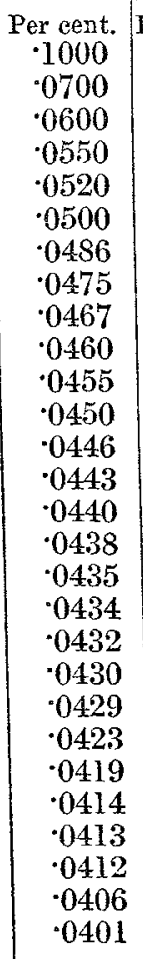 & \begin{tabular}{|c} 
Per cent \\
$n i l$ \\
$30^{\circ}$ \\
$40^{\circ}$ \\
$45^{\circ}$ \\
$48 \cdot$ \\
$50^{\cdot}$ \\
$51 \cdot 4$ \\
$52 \cdot 5$ \\
$53 \cdot 3$ \\
$54 \cdot$ \\
$54 \cdot 5$ \\
$55 \cdot$ \\
$55 \cdot 4$ \\
$55 \cdot 7$ \\
$56 \cdot$ \\
$56 \cdot 2$ \\
$56 \cdot 5$ \\
$56 \cdot 6$ \\
$56 \cdot 8$ \\
$57 \cdot$ \\
$57 \cdot 1$ \\
$57 \cdot 7$ \\
$58 \cdot 1$ \\
$58 \cdot 6$ \\
$58 \cdot 7$ \\
$58 \cdot 8$ \\
$59 \cdot 4$ \\
$59 \cdot 9$
\end{tabular} & 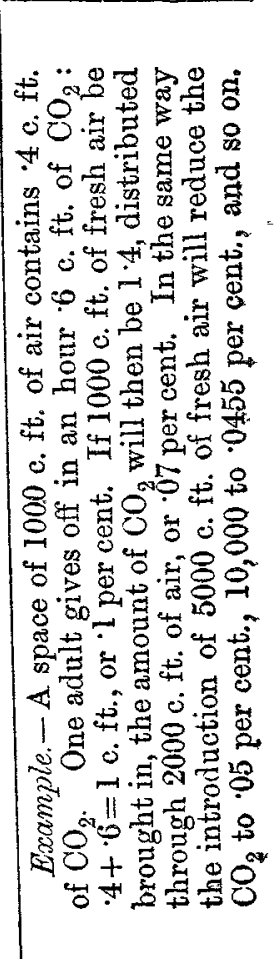 \\
\hline
\end{tabular}

The cubic space taken is 1000 cubic feet, supposed to be 
occupied by one person. At the end of an hour the amount of $\mathrm{CO}_{2}$ present in this 1000 cubic feet of air will be one cubic foot-viz., 4 cubic feet, the normal amount present in all air, and 6 cubic feet, the amount expired by the occupant in one hour. That is: whereas the normal amount is 04 per cent. of $\mathrm{CO}_{2}$, the air (if no renewal take place) will, at the end of an hour contain $\cdot 10$ per cent. Our aim is to supply so much air as will reduce this excess of $\mathrm{CO}_{2}$ as nearly as possible to the normal standard-viz., 04 per cent. Were the air to be supplied entirely free from $\mathrm{CO}_{2}$, then the problem would be simple enough; we should only have to divide $\cdot 10$ by $04=2.5$, and make up the air to $2 \frac{1}{2}$ times the original amount, or add the difference between the original air ( 1000 cubic feet) and the quantity so calculated. This would be $2500-1000=1500$ cubic feet to be added. For if 2500 cubic feet contained 1 of $\mathbf{C ~} \mathrm{O}_{2}$, the ratio would obviously be 04 per cent. But as the incoming air already contains 0.4 per cent., the problem becomes more complex. If in practice we add to 1000 cubic feet, containing one cubic foot of $\mathrm{C} \mathrm{O}_{2}, 1500$ cubic feet of fresh air, we bring in also ${ }^{\circ} 6$ of $\mathrm{C} \mathrm{O}$. The result will be, that the 2500 cubic feet will contain 1.6 of $\mathrm{C} \mathrm{O}_{2}$, or in the ratio of 064 per cent. instead of 04 per cent. A much larger quantity of air must therefore be supplied, and the table will show the reduction consequent on the delivery of different quantities of fresh air. Thus, starting with 1000 cubic feet per head, containing at the end of an hour 10 per cent. of $\mathrm{CO}_{2}$, if we supply 1000 cubic feet of Iresh air (bringing with it 04 per cent. of $\mathrm{C} \mathrm{O}_{2}$ ) we reduce the $\mathrm{CO}_{2}$ to .07 in the whole air. If we supply 5000 cubic feet of fresh air we reduce it to 05 per cent.; if we give 10,000 we reduce it to $\cdot 0455$ per cent., while it would take no less than $1,000,000$ of cubic feet of fresh air to reduce it to -0401 per cent. It is thus obvious that so long as the space is occupiod continuously, no amount of air that can be supplied will reduce the $\mathrm{CO}_{2}$ to the normal standard, and that unless an increasing quantity of air be delivered, the atmosphere must become more and more vitiated. This deduction would, however, be modified by the variable composition of the external air under certain circumstances (from 02 to 05 per cent.), but it is safe to take the average at $\cdot 04$ per cent.

In a badly-ventilated room at Aldershott (March, 1865) the following were the conditions :-Total cubic space, 13,032 feet; number of men, 15 ; cubic space per head, 871 ; total inlet and outlet area per head, nearly 20 square inches; delivery of air that could be measured, 7210 cubic feet per hour, or 480 per man. At this rate the $\mathrm{CO}_{2}$ at five A.M. (the men having been in the room eight hours) would have amonnted to 1418 per cent., but actual observation gave 0962 per cent.; therefore about double the quantity of air, or about 950 cubic feet per head per hour, must have been actually delivered. In this case probably all the air delivered was utilized, but this often does not happen. In the same room in the daytime six people had been one hour; there was a good fire and strong draught; the door was open, and air was rushing into the room at the rate of 105,000 cubic feet an hour. If all this air had been utilized, the $\mathrm{CO}_{2}$ would have been reduced to 013 per cent., or nearly to purity; but actual observation gave 0664 per cent., or more than half as much again, showing that from the form of the room and bad distribution of the current, a great part of the air had escaped without mixing with the atmosphere of the room. In another room, ventilated on a better principle, and where nearly all the movement of air could be measured, the conditions were :- - Total cubic space, 12,984 feet; number of men, 13 ; space per head, 999 cubic feet; total inlet and outlet area per nead, 23 square inches : total delivery of fresh air per hour, 25,519 cubic feet, giving per head, 1963. By calculation at the end of two hours, the ratio of $\mathrm{C} \mathrm{O}_{2}$ would be 0643 per cent.; uy actual observation it was 0642 , or almost identically the same. In this case all the air was utilized.

In a ward at Hilsea Hospital the cubic space was 28,360, the number of patients 17; giving a space per head of 1609 cubic feet ; inlet and outlet area per head, 45.6 square inches. At midnight (the patients had been in for four hours) the $\mathrm{CO}_{2}$ was in the ratio of 0432 per cent. To effect this reduction no less than 21,000 cubic feet of air per head must have entered.

In the observations cited by Dr. F. Smith the $\mathrm{CO}_{2}$ amounted to 056 per cent. during the day, and rose to 0779 at midnight, and to 0781 in the morning. If each inmate had only 500 cubic feet of air-space, then, after four hours' occupation, it would require 3750 cubic feet of fresh air per head to be delivered per hour. To reduce the $\mathrm{CO}_{2}$ to 0779 at midnight, it would require 1800 cubic feet per head per hour; and to reduce it to 0781 at six A.M. it would require 2500 cubic feet per head per hour. This would give, on the whole, an average of about 3200 cubic feet per head per hour in the twenty-four hours. But the result, after all, is anything but satisfactory, the ratio of $\mathrm{CO}_{2}$ at night being nearly double the standard. Besides this, to get even this delivery, and to keep down the velocity of the current of air to 6 feet per second, we should require at least 46 square inches of inlet and outlet area per head, free of all obstructions, and triple that amount if there be louvres or gratings. But to reduce the $\mathrm{CO}_{2}$ to the ratio obtrined at Hilsea we should require, if only 500 cubic feet of air space be given, to deliver 18,250 cubic feet per head per hour. Now, in the Hilsea ward, the rate of movement of the incoming air at the apertures must have been, by calculation, 36 feet per second ; but there was only a difference of $5^{\circ} \mathrm{F}$. between the external and internal air; while the great size of the ward $(28,360$ cubic feet, or 1609 per head) enabled the air to be so distributed as to produce comparatively little draught. But if this ward had beld 54 patients-as it would do on Dr. E. Smith's plan,we should require to bring in 985,500 cubic feet per hour; and to reduce the rate of movement to 36 feet per second, as above, the total inlet and outlet area would have to be raised from 775 square inches to 2217 -an enormous amount. But it is obvious that such a rate as 36 feet per second at the point of entry could only be tolerated under certain circumstances, and that consequently the ventilation would be defective at all other times. Moreover, to secure such a rate of renewal of air would require artificial means to an extent that wonld necessitate much greater expense than would be required to supply at the outset a greater amount of air space. That the amount of delivery of air recommended in the present day (about 2000 cubic feet per head per hour) is still much too small may be seen from the table; but we shall not only not improve the position, but, on the contrary, make it worse, if we diminish the amount of original air space.

Army Medical School, Netley, July 31st, 1866.

\section{A SIMPLE METHOD OF RADICALLY CURING REDUCIBLE HERNIA.}

By JULIAN J. CHISOLM, M.D.,

PROFESSOR OF SURGERY IN TEE MEDICAI COLLEGE OE S. CAROLINA, t.S.1.

A sIMPLE plan for radically curing hernia, which I suggested and put into successful practice in 1859 , consists in sewing the columns of the inguinal ring together, subcutaneously, by silver wire, and leaving the wire permanently in the tissues, so as to act the part of a permanent internal clamp. This restores to a great extent the virgin condition of the external oblique tendon which gives strength and support to the lower portion of the abdomen. The only instrument necessary for the performance of this operation is a stiff needle five inches in length, very slightly curved towards its point, near which is placed the eye. The other extremity of the needle is secured in a firm handle, which enables the surgeon to control its movements.

The various steps of the operation are as follow:-The patient having undergone the usual preparation of having the bowels emptied by some mild cathartic, is placed in the recumbent posture, and all hair is removed from the pubic region corresponding to the side upon which the operation is to be performed. The hernial contents having been returned into the peritoneal cavity, the index-finger of the left hand is placed over the centre of the fundus of the scrotum (palmar surface upwards), the needle lying upon and parallel with it, the eye of the needle corresponding with the pulp of the finger, which can guide it in the direction it should take to the point of transfixion. The finger, with the needle now capped by serotal tissue, is passed up into the inguinal canal until the inner face of the columns can be readily felt. The pulp of the finger having passed well behind the in. ternal column, the handle of the needle is seized, and the point, directed by the finger, is made to transfix the conjoined tendon and internal column at some distance from its free border. When the point of the needle projects under the skin of the abdomen, an assistant draws the skin inward towards the median line, so as to make the needle perforate that portion of skin which would normally lie orer the central portion of the canal. The needle is now threaded with a silver wire and then drawn back into the canal and through the scrotum, 